\title{
A Comprehensive Review of Peri-implantitis Risk Factors
}

\section{Dena Hashim ${ }^{1} \cdot$ Norbert Cionca $^{1}$}

Published online: 27 July 2020

(C) The Author(s) 2020

\begin{abstract}
Purpose of Review This is a comprehensive narrative review aimed at identifying relevant risk factors associated with peri-implantitis. Recent Findings Recent studies suggest that water pipes and electronic cigarettes present potentially significant risk factors for peri-implantitis. In addition, we have recently appreciated that the release of titanium particles into the peri-implant tissues is associated with inflammation and disease progression. Yet the question remains as to whether these factors could be sole or major causes of peri-implantitis, or merely additional factors contributing to the aggravation of the disease. Furthermore, the use of zirconia implants does not prevent the development of peri-implantitis, but it has been associated with lower inflammation and marginal bone resorption.

Summary Established peri-implantitis risk factors include periodontal disease, lack of maintenance, cigarette and smokeless tobacco use, hyperglycaemia and obesity. Local risk factors include inadequate plaque control, mucositis, implant's malposition and poorly designed prostheses or presence of excess cement. Potential risk factors requiring additional research include genetic and systemic conditions, high doses of bisphosphonates and hormonal replacement therapy. Occlusal overload, lack of keratinised tissue and local presence of titanium particles seem to aggravate peri-implant disease, but studies are still required prior to drawing definitive conclusions.
\end{abstract}

Keywords Peri-implantitis $\cdot$ Risk factors $\cdot$ Risk predictors $\cdot$ Biological complications $\cdot$ Implants $\cdot$ Review

\section{Introduction}

Oral implants are currently an essential and routine part of any dental practice. Yet despite their formidable success, complications and failure rates have been progressively rising $[1,2]$. Peri-implantitis is one of the most common biological complications affecting functional implants. It is a destructive inflammatory disease associated with pocket formation and peri-implant bone loss [3]. Marginal bone level changes after initial remodelling, accompanied by bleeding on peri-implant probing (BOP), are recommended for its diagnosis [3]. Periimplantitis affects around $13 \%$ of implants and $18.5 \%$ of

This article is part of the Topical Collection on Peri-implantitis

Dena Hashim

dena.hashim@unige.ch

Norbert Cionca

norbert.cionca@unige.ch

1 Division of Regenerative Dental Medicine and Periodontology, University of Geneva, 1 Rue Michel-Servet, CH-1211 Genève 4, Switzerland patients [4], with its incidence rising from 0.4 to $43.9 \%$ within $3-5$ years $[5 \cdot]$. However, the disease affects different subjects and different implants at variable rates. Despite its predominantly bacterial aetiology [6,7], various factors may increase the risk of developing peri-implantitis. Whether inherent or modifiable, the identification of these factors is crucial for both prevention and treatment of the disease.

Since peri-implantitis presents a public health issue $[4,8$, 9], this review aims to describe all relevant risk factors in order to identify susceptible patients and implants. This will help the development of individualised maintenance programs, eventually contributing to the primary prevention of the disease.

\section{Peri-implantitis Risk Factors}

\section{Patient-Related Risk Factors}

\section{Periodontal Disease and Microbiological Aspects}

The diagnosis, or history, of periodontal disease is the most researched factor associated with peri-implantitis. This is 
partially attributed to similarities in the subgingival microbiota between the diseased teeth and implants [10 $]$. Submucosal presence of certain periodontal pathogens has been significantly associated with peri-implantitis, with an odds ratio of 15.1 [11], but the results are still controversial [12]. Current data suggests that peri-implantitis is associated with a specific microbiota resembling that of periodontal lesions, in addition to other microorganisms not commonly related to periodontitis [13]. Nevertheless, it is well-accepted that peri-implantitis consistently presents with marked microbial diversity [13, 14], and that deeper peri-implant pockets exhibit significant microbial alterations and higher levels of dysbiosis [15].

Periodontal disease has been strongly associated with periimplantitis $[5 \cdot 16]$. Active periodontitis at the adjacent teeth is further considered a predictor of future peri-implantitis [9]. Periodontally compromised patients have twice the risk of developing peri-implantitis compared with healthy individuals [10•]. Moreover, those with a history of generalised aggressive periodontitis are 5 times more prone to implant failure, and 14 times more susceptible to peri-implantitis, compared with healthy controls [17]. Fortunately, successful treatment of periodontal disease prior to implant placement has been shown to lower the risk of peri-implantitis [18], and is therefore considered an essential initial part of the overall treatment plan.

\section{Lack of Maintenance Therapy}

Supportive therapy has been shown to significantly lower the risk of peri-implant biological complications, and a minimum recall interval of 5-6 months has thus been recommended [18, 19]. Maintenance programs should be tailored to the individual's specific needs and susceptibility to both periodontal and peri-implant diseases. Factors used for risk assessment include the percentage of BOP, the prevalence of active residual pockets, oral hygiene level, smoking habits and the presence of systemic or genetic conditions [20]. Individuals with high-risk profiles require three to four annual visits [20,21], and their attendance is detrimental for prevention and early detection of peri-implantitis [22]. One out of five non-compliant patients is diagnosed with periimplantitis within 5 years [23]. On the other hand, compliance is associated with $86 \%$ fewer peri-implantitis cases. Unfortunately, those with greater needs have been known to be the least compliant. The extent and severity of periodontal disease, as well as the patient's smoking habits, affect adherence to maintenance programs [22]. Therefore, it is the clinicians' duty to adequately inform their patients of the importance of regular supportive therapy for the prevention of peri-implantitis.

\section{Smoking Including Cigarettes, Water pipes, Smokeless Tobacco, Vaping and Cannabis}

The negative effects of smoking on periodontal health have long been well established. It impacts innate and adaptive immune responses, impairing the host's defence mechanisms and its response to microbial challenges [24, 25]. Cigarette smoking also affects wound healing, as it is therefore detrimental to periodontal treatment [21, 26, 27]. Smoking further increases the oxidative stress and inflammatory burden with marked alterations in microbial flora [28]. It significantly affects implants' colonisation with periodontal pathogens such as Porphyromonas gingivalis (Pg) and Fusobacterium nucleatum [28]. Besides, cigarettes are not only harmful to smokers, but mere exposure to environmental smoke increases the risk of developing periodontal disease by $28 \%$ [29].

Studies have repeatedly proven smoking as a risk factor for peri-implantitis $[9,30,31]$. Smokers are almost twice more at risk of developing peri-implantitis compared with nonsmokers [5•]. Moreover, smoking is associated with increased severity of peri-implantitis lesions [16], with a dosedependant relationship between smoking and tissue destruction [26, 32]. Nevertheless, smoking cessation has been shown to positively impact periodontal health, with favourable effects on both incidence and progression of the disease $[26,33]$.

In addition to cigarettes commerciality, the popularity of non-cigarette tobacco products has been alarmingly rising. Water pipes, also known as shisha, hookah or narjilah, have become a popular way of smoking tobacco among adolescents and adults alike [34, 35]. Their recreational use has become widely acceptable despite containing high levels of nicotine, and a multitude of carcinogens and heavy metals. In addition, water pipes emit a variety of pollutants generated by the charcoal used to heat the tobacco. They are smoked for hours in social settings, thus extending the amount of smoke inhalation and its side effects. Secondhand smoke inhalation should also be taken into account. The link between water pipe smoking and periodontal disease has already been established by several studies $[35,36]$. Furthermore, water pipe smokers have a significantly higher risk of periodontitis compared with cigarette smokers, but adverse effects were strongly associated with the duration and the quantity of daily use [37]. However, studies have so far focused on periodontal conditions in general, and not on peri-implantitis in particular. But in analogy to cigarette smoking, water pipe smoking presents a possible risk factor for peri-implant disease.

Smokeless tobacco is yet another factor associated with periodontal disease, specially in the absence of adequate oral hygiene measures [38]. It is most commonly used in India and Southeast Asia [39]. The adverse effects of smokeless tobacco on both periodontal and peri-implant tissues are comparable with those of cigarette smoking [40, 41]. Deeper probing depths and higher degrees of peri-implant bone loss were found in cigarette smokers and smokeless tobacco users compared with non-tobacco users [41]. 
Electronic cigarettes (e-cigarettes), or vaping, have lately become an extremely widespread trend among individuals of all ages. They are widely misconceived as harmless recreational products. Yet their increasing popularity, combined with the lack of evidence on long-term health effects, has become rather disquieting [42]. Regardless of their nicotine content, e-cigarettes have been shown to increase oxidative/ carbonyl stress and pro-inflammatory responses, with adverse effects on endothelial cells and fibroblasts, and concomitant dysregulation in periodontal repair [43-45]. Clinical studies have associated vaping with periodontal attachment loss and marginal bone resorption [44, 46]. A recent cross-sectional study had further demonstrated significantly deeper periimplant probing depths and increased marginal bone loss in vaping patients compared with never smokers. However, this study did not account for past cigarette smoking as a confounding factor that could have influenced the results [45]. Further research is required to shed the light on the extent and severity of peri-implant complications, as well as the impact of vaping on general health.

Among smokable illicit substances, cannabis is one of the most commonly used drugs worldwide $[47,48 \bullet$. Following its recent legalisation in several countries, the plausibility of an association between cannabis and peri-implantitis should be evaluated. Different studies have already established higher prevalence and severity of periodontitis in cannabis users, irrespective of concomitant tobacco smoking [48, 49$]$. However, an animal study demonstrated bone loss on the periodontitis-affected teeth exposed to cannabis without significantly affecting the periodontally healthy teeth [50]. Meaning that cannabis only seems to aggravate periodontitis-associated bone loss. Since periodontitis is more prevalent in adults [51,52], this could explain why clinical studies showed a higher impact of cannabis on older individuals compared with adolescents. However, the drug's mechanism of action and its exact pathway to periodontal destruction is still unclear [48•,53]. Finally, despite studies supporting an association between cannabis use and periodontitis, the evidence is still lacking regarding peri-implantitis.

\section{Systemic Conditions}

The influence of certain systemic diseases on periodontal health has long been established [54-56]. Due to its increasing prevalence, diabetes mellitus is one of the most thoroughly researched conditions in the literature. It affects 415 million adults worldwide, with 642 million projected in 2040 (The International Diabetes Federation; 2015). The disease affects insulin's secretion, its function or both, causing disruption of glycaemic levels. This consequently results in a variety of neuropathological, retinal, microvascular and renal complications [57].
Poor glycaemic control plays a pivotal role in the progression and severity of periodontitis [58]. This association has been explained by several vascular and cellular responses, leading to enhanced tissue destruction and impaired healing response [59]. Similar mechanisms are triggered in periimplant tissues; resulting in a higher susceptibility to periimplantitis in individuals suffering from hyperglycaemia [56]. Poorly controlled diabetics are at $46 \%$ higher risk of developing peri-implantitis, with deeper peri-implant pockets and higher marginal bone loss, compared with their normoglycaemic controls [55]. Interestingly, smokers and poorly controlled diabetics are considered at a similar risk for peri-implantitis. On the other hand, non-smokers with poor glycaemic control are 3.39 times at higher risk of developing peri-implantitis compared with normoglycaemic individuals [56]. Therefore, hyperglycaemia, not diabetes per se [60••], presents a significant risk factor for peri-implantitis.

Obesity is another highly prevalent condition with detrimental effects on periodontal health $[61,62]$. It is defined as abnormal or excessive body fat accumulation with debilitating effects on general health [63]. This is a major medical problem associated with marked physiological changes, including diabetes mellitus and coronary heart disease [64]. Obesity is also associated with a generalised and constant hyper-inflammatory state, causing an altered immune response and increased production of proinflammatory cytokines, which adversely affect periodontal tissues and alveolar bone levels [31, 65]. Clinical studies have established obesity as a risk factor for peri-implantitis $[62,66$, 67]. When compared with individuals with normal body weight, obese patients present with significantly higher percentages of BOP, deeper peri-implant probing depths and increased marginal bone loss [66, 67]. The severity of peri-implant inflammation is significantly associated with the level of obesity [62].

Despite their prevalence, few studies have examined the association between cardiovascular diseases and periimplantitis. Most showed a significantly higher risk of periimplantitis and additional bone loss for patients suffering from heart disease [54, 68, 69]. Yet the results are still controversial $[54,70]$. The influence of such conditions on implants' success should be further explored in larger studies with adequate methodology.

Discussions have also been raised regarding the effect of different autoimmune diseases on peri-implantitis, but conclusions cannot be drawn due to the scarcity of evidence [54]. Rheumatoid arthritis with concomitant connective tissue disease had been associated with higher percentages of BOP and periimplant bone loss in one study [71]. Another study [72] evaluated patients with Sjögren's syndrome but could not show an increased prevalence of peri-implantitis. Yet the higher prevalence of mucositis in the diseased group might indicate an increase in their susceptibility to peri-implantitis over time. Further research is still required to shed the light on the association between autoimmune diseases and peri-implantitis. 
While osteoporosis could not be linked to peri-implantitis, anti-resorptive medications, including bisphosphonates (BP) and hormone replacement therapy (HRT), have been gaining increasing attention. One study [73] showed significant increase in marginal bone loss and implant thread exposure with BP intake. However, a recent systematic review [74•] showed that a low-dose BP did not negatively affect peri-implant bone levels. On the other hand, HRT significantly compromised marginal bone levels. Still, the considerable risk of medication-related osteonecrosis, and its negative influence on peri-implant hard tissues, should not be underestimated.

\section{Genetic Factors}

Despite the general belief in a certain genetic predisposition to peri-implantitis, a clear association with specific risk factors is still to be determined [75]. Interleukin-1 (IL-1) polymorphism is the single most researched genetic factor in the literature. This is mainly due to the involvement of this gene cluster in the encoding of two main pro-inflammatory cytokines, IL- $1 \alpha$ and IL- $1 \beta$, as well as the anti-inflammatory IL- 1 receptor antagonist. Increasing levels of both IL- $1 \alpha$ and IL- $1 \beta$ have been associated with peri-implantitis, and their levels were correlated with the severity of the disease $[75,76]$. Yet, studies evaluating the correlation between IL-1 polymorphism and peri-implantitis have shown conflicting results [75, 77-79]. While several investigations $[76,78]$ could not find a significant association between the two conditions, a recent study [79] showed that subjects with IL-1 polymorphisms were 1.92.47 times more at risk of developing peri-implantitis. Discussions have also been raised regarding a synergistic effect of smoking on individuals with IL-1 polymorphisms without reaching a consensus [76, 80].

Tumour necrosis factor-alpha (TNF- $\alpha$ ) is another proinflammatory cytokine associated with peri-implant inflammation and bone destruction [75]. Studies have shown that TNF- $\alpha$ polymorphism increased the risk of peri-implantitis five to eightfold $[75,81]$. Yet, the meta-analysis of relevant studies could not establish a significant correlation [82].

Very few studies have examined other genetic polymorphisms, and conclusions cannot be extrapolated due to the scarcity of the evidence [75]. Currently, only preliminary investigations, including a wide variety of ethnic groups, have evaluated other genetic markers in association with biological implant complications. Additional research is still required, with larger sample sizes and reduced levels of bias.

\section{Occlusal Overload and Para-Functional Habits}

Occlusal overload of implant-supported prostheses is a controversial subject, and the exact mechanism in which it causes marginal bone loss is still debatable $[83,84]$. Yet several studies have demonstrated that overloading an implant beyond a certain threshold leads to marginal bone loss $[83,85,86]$. Moreover, under similar overload, peri-implantitis-affected sites show significantly higher marginal bone loss compared with those with mucositis [87]. Also, the patterns of bone resorption varied significantly around overloaded implants and those with ligatureinduced peri-implantitis [84]. The effect of overloading on periimplant bone levels can be accentuated by sub-optimal implant positioning, poorly designed prosthetic reconstructions, inadequate bone quantity or its poor quality. Para-functional habits leading to elevated non-axial occlusal forces may also increase marginal bone loss [83]. On the contrary, several animal studies demonstrate an insignificant effect of overload on bone levels in the absence of inflammation $[83,88,89]$. Unfortunately, ethical reasons impede resolution of such controversy using controlled clinical trials with experimental periodontitis models or intentionally overloaded implants.

Attrition and wear of natural dentition or prosthetic reconstructions may be used for diagnosis of occlusal overload and parafunctional habits. The presence of wear facets on implantsupported prostheses is associated with a 2.4 increase in the prevalence of peri-implantitis [90]. However, case reports [91, 92] have demonstrated that occlusal adjustment may result in marked peri-implant bone repair. Therefore, occlusal overload may be considered a potential risk factor for peri-implant bone loss, with an aggravating influence on peri-implantitis-associated bone loss.

\section{Site-Specific Risk Factors}

\section{Implant Material and Surface Characteristics}

The influence of an implant's surface topography on its susceptibility to peri-implantitis is still debatable $[4,5 \cdot, 90,93,94]$. The implant's roughness and surface energy have an impact on initial biofilm formation, but its long-term effect on the inflammatory process and bone stability is still controversial $[93,95,96]$. Few studies demonstrated that rough implants were more susceptible to peri-implantitis [5•,97], while others could not show a significant difference between rough and moderately rough surfaces $[5 \cdot 98]$. A recent systematic review [4] calculated that moderately rough implants are three times less affected by peri-implantitis compared with rough or machined ones. Yet another review published only a year earlier [99•] completely contradicted these results. The later found significantly lower bone loss around minimally rough surfaces compared with moderately rough and rough ones. However, the longer follow-up periods of both minimally rough and rough implants in comparison with the new generation of moderately rough fixtures should be taken into consideration. Moreover, the presence of other risk factors could not always be ruled out. Therefore, definite conclusions cannot be drawn regarding the effect of an implant's topography on periimplantitis.

So far, titanium has been the material of choice in implant dentistry. Nonetheless, zirconia ceramic implants have been 
progressively emerging [100]. Zirconia's greatest assets lie in its biocompatibility, superior soft tissue integration [101, $102 \cdot 0]$, low affinity to plaque [103] and reduced inflammatory processes when compared with titanium [104, 105]. It was hence hypothesised that zirconia implants would finally offer the solution for peri-implant disease. Unfortunately, a recent animal study had clearly demonstrated that zirconia implants can be affected by peri-implantitis [106•]. Still, zirconia demonstrated significantly lower marginal bone loss compared with titanium implants with similar surface topographies. Clinical studies have also demonstrated different degrees of bone loss around zirconia implants with variable designs [107], but additional long-term data is still required to establish both prevalence and treatment protocols.

\section{Implant Type and Prosthetic Design}

The design of the prosthetic reconstruction largely contributes to the implants' long-term success. Poorly designed superstructures significantly impede plaque control, which increases the risk of developing peri-implant disease [21, 108]. Patients with higher plaque indexes were predicted to be 7.9 times more at risk of developing peri-implantitis [9]. Moreover, the relationship between the implant and its prosthetic superstructure, whether centerer or offset, significantly affects its prognosis. An asymmetric prosthesis with a suboptimal emergence profile favours plaque accumulation, consequently increasing the risk of peri-implantitis 4.3 times [9, 109]. A poor marginal fit is also a detrimental risk factor for the development of peri-implantitis [16].

Cemented implant restorations are 3.6 times more prone to peri-implantitis compared with screw-retained ones [90]. This is mostly attributed to the risk of leaving excess cement in the sub-mucosal region, especially when resin luting agents are utilised [110]. Therefore, deep sub-mucosal margins should be avoided in order to provide sufficient visibility and access for cement removal [111].

Full-mouth implant-supported fixed reconstructions have been associated with a 16-fold increase in peri-implantitis compared with single crowns [90]. This was mainly due to poor accessibility for plaque control. Furthermore, a history of advanced periodontal disease, leading to extensive loss of natural dentition, could not be ruled out in cases requiring complete rehabilitation.

Bone-level implant designs, combined with convex restorations at an angle exceeding $30^{\circ}$, significantly augment the risk of peri-implantitis [109]. Platform switching has been recommended to reduce peri-implant bone loss, but its benefits are still debatable [112]. Nevertheless, a systematic review evaluating earlier systematic analyses favoured platform switching for periimplant bone preservation [113]. This could be due to the relocation of the microgap between the implant and the abutment. This microgap is wide enough to allow for bacterial colonisation, and its horizontal offset away from the bone is believed to reduce the risk of peri-implant inflammation [114•]. Platform switching has also been supported by a recent clinical study which showed a significantly reduced probability of developing peri-implantitis [115]. Another reason for advocating platform switching is the reduced amounts of tribocorrosion products released into periimplant tissues. Alrabeah et al. [116•] had demonstrated that platform-matched implants released higher amounts of metal ions, and exhibited more surface damage, compared with platform-switched implants. But keep in mind that the association between titanium particles' release and peri-implantitis is still debatable [117••].

Therefore, tissue-level implant designs are recommended for non-aesthetic implant restorations due to the supramucosal location of the microgap and their accessibility for plaque control. When bone-level implants are indicated, platform switching is advisable with screw-retained superstructures and anatomically shaped emergence profiles. Screwretained prosthesis is also easily retrievable when better visibility and access are required for treatment.

\section{Peri-Implant Soft Tissue Conditions}

The soft tissue condition around an implant may influence its susceptibility to peri-implant disease. Patients with thin periodontal phenotypes are more prone to peri-implant mucosal recessions [118]. The exposure of an implant's rough surface to the oral cavity complicates plaque control and enhances bacterial adhesion, thus leading to a potential increase in its susceptibility to peri-implantitis. A recent clinical study had demonstrated a significant association between thin biotypes and the severity of peri-implantitis [119]. Yet the lack of additional research precludes definitive conclusions.

A minimal $2 \mathrm{~mm}$ zone of keratinised soft tissue (KT) has been advocated for peri-implant health and long-term stability. Yet its absolute necessity is still controversial $[60 \bullet \cdot, 120]$. It has been associated with better plaque control, lower soft-tissue inflammation, mucosal recession and attachment loss [121]. Brushing discomfort and higher plaque scores have been reported at sites with insufficient KT, even in patients with generally good oral hygiene $[122,123]$. Moreover, peri-implantitis and marginal bone loss have been associated with KT width $<2 \mathrm{~mm}[23,123,124]$, particularly in patients not compliant with regular supportive therapy [125]. On the other hand, periodic maintenance resulted in a low incidence of peri-implant disease regardless of the width of KT [126]. Finally, despite the lack of evidence regarding a direct association with peri-implantitis, a 2-mm band of KT is highly recommended.

\section{latrogenic Factors}

While the number of implants does not seem to influence the risk for peri-implantitis [127], their position is critical for long-term success [128]. Implant malpositioning represents a significant 
risk factor for peri-implantitis [128]. Crestal bone resorption could occur when an implant is placed too close to the natural teeth or even other implants [129]. This could compromise access for plaque control, and thus increase the risk of peri-implant disease. Also, fixtures located outside the bony envelope or those with thin facial bone $(<1 \mathrm{~mm})$ are more prone to mucosal recession, especially in patients with thin biotypes. This exposure of the fixture's rough surface increases plaque retention [118], and thus the risk of peri-implantitis. Bone and/or soft tissue grafting is recommended in such cases [129], keeping in mind that augmentation procedures do not increase the risk of biological complications [130].

Moreover, placing an implant $6 \mathrm{~mm}$ or more apical to the cemento-enamel junction of the neighbouring teeth increases its risk of peri-implantitis 8.5 times [9]. A deep sub-mucosal position also complicates plaque control and increases the susceptibility to peri-implant inflammation $[9,21]$.

\section{Bio-Corrosion and Presence of Titanium Particles}

Despite the availability of zirconia implants, titanium remains the material of choice in implantology. However, the release of titanium particles, and their impact on peri-implant tissues, has recently become subjects of heated debates [117••, 131]. Mechanical wear, chemical corrosion and implant surface treatment have been suggested as sources of titanium in the oral environment [132]. The term « tribocorrosion » has been used to describe the combination of wear and corrosion processes [133]. More specifically, corrosion can be observed once mechanical wear has disrupted the protective titanium oxide layer. This is not only confined to the surface of the implant, but can also affect the implant-abutment interface [116•]. From this perspective, the location of the microgap and the quality of the abutment connection are of major importance. From there on, tribocorrosion becomes auto-sustained, since a corroded surface becomes less resistant to mechanical wear.

Microbial contamination could also lead to the release of titanium particles. The acidic inflammatory environment contributes to the oxidation and destruction of the superficial implant layer, and hence the release of metal ions. This consequently amplifies peri-implant inflammation and disease progression [134]. The local release of titanium has also been associated with lipopolysaccharides producing gram-negative bacteria, such as $\mathrm{Pg}$, and an over-expression of pro-inflammatory cytokines [135]. Greater levels of titanium particles have been detected in peri-implant soft tissue biopsies taken from fixtures with peri-implantitis compared with healthy sites [136, 137].

Certain peri-implantitis therapeutic measures may further contribute to titanium's release into the peri-implant region. This includes chemicals used for implant surface decontamination, such as chlorhexidine and hydrogen peroxide [138], and mechanical devices like ultra-sonic tips. Implantoplasty, frequently used to remove exposed implant spears and polish rough surfaces, has also been associated with significant release of metallic particles [131, 139]. Moreover, titanium's dissemination into distant organs, such as the lungs and lymph nodes, should be considered [134].

Regardless of the source, it remains to be determined if titanium particles could be the sole cause of peri-implantitis, or merely a consequence of microbiological, chemical and mechanical factors. Moreover, the effect of the particle's size should be taken into account. Nanoparticles have a higher biological activity and hence are significantly more harmful than microparticles. Also, keep in mind that harmless levels of titanium oxide are commonly found in cosmetics, toothpastes, suncreams and even various food products [117••].

\section{Poor Plaque Control and Peri-Implant Mucositis}

A patient's self-performed plaque control is one of the most important factors influencing the implant's prognosis [23, 60••, 108]. A high plaque index was associated with an eightfold increase in susceptibility to peri-implantitis [9]. The accumulation of bacterial biofilm on implant and abutment surfaces leads to peri-implant inflammation, also known as mucositis [140••]. This cause-and-effect relationship has been further validated by the complete resolution of experimental mucositis once oral hygiene measures have been reinstated [140••, 141].

Peri-implantitis is always preceded by a period of mucositis. The two share several risk factors including poor oral hygiene, smoking and sub-mucosal presence of excess cement [140••]. However, not all mucositis lesions progress to peri-implantitis, even when present for extensive periods of time [142]. Conversion to peri-implantitis is more likely to occur in patients non-compliant with regular supportive implant therapy, with an odds ratio of 5.92 [143]. A concomitant effect of different previously described risk factors could lead to the onset of periimplantitis. Nevertheless, implants diagnosed with mucositis are at risk of developing peri-implantitis [140••].

\section{Conclusions}

- Peri-implantitis is a common, complex and multifactorial disease. Among its established risk factors are periodontal disease, lack of maintenance, cigarette and smokeless tobacco use, hyperglycaemia and obesity. Local risk factors include inadequate plaque control, mucositis, implant's malposition and poorly designed prosthesis or presence of excess cement.

- Certain genetic factors, cardiovascular and autoimmune diseases and high-dose BP and HRT could increase the susceptibility to peri-implantitis, but the evidence is still contradictory.

- Water pipe smoking and vaping significantly affect periodontal tissues and should hence be considered potential 
risk factors for peri-implantitis. But additional research is still required for association with peri-implantitis.

- Occlusal overload and presence of titanium particles may contribute to the onset and progression of the disease.

Keep in mind that not all high-risk implants, nor those placed in highly susceptible patients, will develop periimplantitis. Nevertheless, identifying susceptible implants and patients will help in the tailoring supportive treatment to the patient's need, thus contributing to the primary prevention of the disease. Clinicians should be conscious of the risk periodontal disease present for future biological complications. They should also consider the ramifications of their implant and prosthetic choices, weighing their advantages against their risks. Raising patient awareness regarding modifiable risk factors, such as plaque control and smoking, should also become an integral part of the overall treatment planning. Finally, risk assessment and patient education should take place prior to implant placement, and not in a retrospective manner.

Funding Information Open access funding provided by University of Geneva.

\section{Compliance with Ethical Standards}

Conflict of Interest The authors declare that they have no conflict of interest.

Human and Animal Rights and Informed Consent This article does not contain any studies with human or animal subjects performed by any of the authors.

Open Access This article is licensed under a Creative Commons Attribution 4.0 International License, which permits use, sharing, adaptation, distribution and reproduction in any medium or format, as long as you give appropriate credit to the original author(s) and the source, provide a link to the Creative Commons licence, and indicate if changes were made. The images or other third party material in this article are included in the article's Creative Commons licence, unless indicated otherwise in a credit line to the material. If material is not included in the article's Creative Commons licence and your intended use is not permitted by statutory regulation or exceeds the permitted use, you will need to obtain permission directly from the copyright holder. To view a copy of this licence, visit http://creativecommons.org/licenses/by/4.0/.

\section{References}

Papers of particular interest, published recently, have been highlighted as:

- Of importance

-• Of major importance

1 Jung RE, Zembic A, Pjetursson BE, Zwahlen M, Thoma DS. Systematic review of the survival rate and the incidence of biological, technical, and aesthetic complications of single crowns on implants reported in longitudinal studies with a mean follow-up of 5 years. Clin Oral Implant Res. 2012;23(Suppl 6):2-21. https:// doi.org/10.1111/j.1600-0501.2012.02547.x.

2 Pjetursson BE, Thoma D, Jung R, Zwahlen M, Zembic A. A systematic review of the survival and complication rates of implantsupported fixed dental prostheses (FDPs) after a mean observation period of at least 5 years. Clinical Oral Implant Res. 2012;23(Suppl 6):22-38. https://doi.org/10.1111/j.1600-0501.2012.02546.x.

3 Berglundh T, Armitage G, Araujo MG, Avila-Ortiz G, Blanco J, Camargo PM, et al. Peri-implant diseases and conditions: consensus report of workgroup 4 of the 2017 World Workshop on the Classification of Periodontal and Peri-Implant Diseases and Conditions. J Periodontol. 2018;89(Suppl 1):S313-S8. https:// doi.org/10.1002/JPER.17-0739.

4 Rakic M, Galindo-Moreno P, Monje A, Radovanovic S, Wang HL, Cochran D, et al. How frequent does peri-implantitis occur? A systematic review and meta-analysis. Clin Oral Investig. 2018;22(4):1805-16. https://doi.org/10.1007/s00784-017-2276-y.

5 - Dreyer H, Grischke J, Tiede C, Eberhard J, Schweitzer A, Toikkanen SE, et al. Epidemiology and risk factors of periimplantitis: A systematic review. J Periodontal Res. 2018;53(5): 657-81. https://doi.org/10.1111/jre.12562 Recent literature reviews detailing different peri-implantitis risk factors.

6. Rosenberg ES, Torosian JP, Slots J. Microbial differences in 2 clinically distinct types of failures of osseointegrated implants. Clin Oral Implants Res. 1991;2(3):135-44.

7. Robitaille N, Reed DN, Walters JD, Kumar PS. Periodontal and peri-implant diseases: identical or fraternal infections? Mol Oral Microbiol. 2016;31(4):285-301. https://doi.org/10.1111/omi. 12124.

8. Lee CT, Huang YW, Zhu L, Weltman R. Prevalences of periimplantitis and peri-implant mucositis: systematic review and meta-analysis. J Dent. 2017;62:1-12. https://doi.org/10.1016/j.jdent. 2017.04.011.

9. Kumar PS, Dabdoub SM, Hegde R, Ranganathan N, Mariotti A. Site-level risk predictors of peri-implantitis: a retrospective analysis. J Clin Periodontol. 2018;45(5):597-604. https://doi.org/10. 1111/jcpe. 12892.

10 - Ferreira SD, Martins CC, Amaral SA, Vieira TR, Albuquerque $\mathrm{BN}$, Cota LOM, et al. Periodontitis as a risk factor for periimplantitis: systematic review and meta-analysis of observational studies. J Dent. 2018;79:1-10. https://doi.org/10.1016/j.jdent. 2018.09.010 Recent literature reviews detailing different peri-implantitis risk factors.

11. de Waal YC, Eijsbouts HV, Winkel EG, van Winkelhoff AJ. Microbial characteristics of peri-implantitis: a case-control study. J Periodontol. 2017;88(2):209-17. https://doi.org/10.1902/jop. 2016.160231.

12. Schmalz G, Tsigaras S, Rinke S, Kottmann T, Haak R, Ziebolz D. Detection of five potentially periodontal pathogenic bacteria in peri-implant disease: a comparison of PCR and real-time PCR. Diagn Microbiol Infect Dis. 2016;85(3):289-94. https://doi.org/ 10.1016/j.diagmicrobio.2016.04.003.

13. Faveri M, Figueiredo LC, Shibli JA, Perez-Chaparro PJ, Feres M. Microbiological diversity of peri-implantitis biofilms. Adv Exp Med Biol. 2015;830:85-96. https://doi.org/10.1007/978-3-31911038-7_5.

14. Canullo L, Penarrocha-Oltra D, Covani U, Rossetti PH. Microbiologic and clinical findings of implants in healthy condition and with peri-implantitis. Int J Oral Maxillofac Implants. 2015;30(4):834-42. https://doi.org/10.11607/jomi.3947.

15. Kroger A, Hulsmann C, Fickl S, Spinell T, Huttig F, Kaufmann F, et al. The severity of human peri-implantitis lesions correlates with the level of submucosal microbial dysbiosis. J Clin Periodontol. 2018;45(12):1498-509. https://doi.org/10.1111/jcpe.13023. 
16. Saaby M, Karring E, Schou S, Isidor F. Factors influencing severity of peri-implantitis. Clin Oral Implants Res. 2016;27(1):7-12. https://doi.org/10.1111/clr.12505.

17. Swierkot K, Lottholz P, Flores-de-Jacoby L, Mengel R. Mucositis, peri-implantitis, implant success, and survival of implants in patients with treated generalized aggressive periodontitis: 3 - to 16year results of a prospective long-term cohort study. J Periodontol. 2012;83(10):1213-25. https://doi.org/10.1902/jop.2012.110603.

18. Renvert S, Quirynen M. Risk indicators for peri-implantitis. A narrative review. Clin Oral Implants Res. 2015;26(Suppl 11): 15-44. https://doi.org/10.1111/clr.12636.

19. Monje A, Aranda L, Diaz KT, Alarcon MA, Bagramian RA, Wang $\mathrm{HL}$, et al. Impact of maintenance therapy for the prevention of periimplant diseases: a systematic review and meta-analysis. J Dent Res. 2016;95(4):372-9. https://doi.org/10.1177/0022034515622432.

20. Lang NP, Suvan JE, Tonetti MS. Risk factor assessment tools for the prevention of periodontitis progression a systematic review. J Clin Periodontol. 2015;42(Suppl 16):S59-70. https://doi.org/10. $1111 /$ jcpe. 12350.

21. Armitage GC, Xenoudi P. Post-treatment supportive care for the natural dentition and dental implants. Periodontol. 2016;71(1): 164-84. https://doi.org/10.1111/prd.12122.

22. Monje A, Wang HL, Nart J. Association of preventive maintenance therapy compliance and peri-implant diseases: a crosssectional study. J Periodontol. 2017;88(10):1030-41. https://doi. org/10.1902/jop.2017.170135.

23. Rokn A, Aslroosta H, Akbari S, Najafi H, Zayeri F, Hashemi K. Prevalence of peri-implantitis in patients not participating in welldesigned supportive periodontal treatments: a cross-sectional study. Clin Oral Implants Res. 2017;28(3):314-9. https://doi.org/ 10.1111/clr.12800.

24. Palmer RM, Wilson RF, Hasan AS, Scott DA. Mechanisms of action of environmental factors-tobacco smoking. J Clin Periodontol. 2005;32(Suppl 6):180-95. https://doi.org/10.1111/j. 1600-051X.2005.00786.x.

25. Johnson GK, Guthmiller JM. The impact of cigarette smoking on periodontal disease and treatment. Periodontol. 2007;44:178-94. https://doi.org/10.1111/j.1600-0757.2007.00212.x.

26. Johannsen A, Susin C, Gustafsson A. Smoking and inflammation: evidence for a synergistic role in chronic disease. Periodontol. 2014;64(1):111-26. https://doi.org/10.1111/j.1600-0757.2012.00456.

27. Trombelli L, Farina R, Minenna L, Toselli L, Simonelli A. Regenerative periodontal treatment with the single flap approach in smokers and nonsmokers. Int J Period Restor Dent. 2018;38(4): e59-67. https://doi.org/10.11607/prd.3615.

28. Geisinger ML, Geurs NC, Ogdon D, Reddy MS. Commentary: targeting underlying biologic mechanisms in selecting adjunctive therapies to improve periodontal treatment in smokers: a commentary. J Periodontol. 2017;88(8):703-10. https://doi.org/10.1902/ jop.2017.170098.

29. Sutton JD, Salas Martinez ML, Gerkovich MM. Environmental tobacco smoke and periodontitis in United States non-smokers, 2009 to 2012. J Periodontol. 2017;88(6):565-74. https://doi.org/ 10.1902/jop.2017.160725.

30. Gurlek O, Gumus P, Buduneli N. Smokers have a higher risk of inflammatory peri-implant disease than non-smokers. Oral Dis. 2018;24(1-2):30-2. https://doi.org/10.1111/odi.12730.

31. Pham TAV, Kieu TQ, Ngo LTQ. Risk factors of periodontal disease in Vietnamese patients. J Investig Clin Dent. 2018;9(1). doi: https://doi.org/10.1111/jicd.12272.

32. Albandar JM, et al. Periodontol. 2002;29:177-206.
33. Preshaw PM, Heasman L, Stacey F, Steen N, McCracken GI, Heasman PA. The effect of quitting smoking on chronic periodontitis. J Clin Periodontol. 2005;32(8):869-79. https://doi.org/10. 1111/j.1600-051X.2005.00779.x.

34. Arrazola RA, Dube SR, King BA. Tobacco product use among middle and high school students - United States, 2011 and 2012. MMWR Morb Mortal Wkly Rep. 2013;62(45):893.

35. Kim KH, Kabir E, Jahan SA. Waterpipe tobacco smoking and its human health impacts. J Hazard Mater. 2016;317:229-36. https:// doi.org/10.1016/j.jhazmat.2016.05.075.

36. Cobb CO, Sahmarani K, Eissenberg T, Shihadeh A. Acute toxicant exposure and cardiac autonomic dysfunction from smoking a single narghile waterpipe with tobacco and with a "healthy" tobacco-free alternative. Toxicol Lett. 2012;215(1):70-5. https:/ doi.org/10.1016/j.toxlet.2012.09.026.

37. Natto S, Baljoon M, Bergstrom J. Tobacco smoking and periodontal health in a Saudi Arabian population. J Periodontol. 2005;76(11):1919-26. https://doi.org/10.1902/jop.2005.76.11. 1919.

38. Giovannoni ML, Valdivia-Gandur I, Lozano de Luaces V, Varela Veliz H, Balasubbaiah Y, Chimenos-Kustner E. Betel and tobacco chewing habit and its relation to risk factors for periodontal disease. Oral Dis. 2018;24(5):829-39. https://doi.org/10.1111/odi. 12820.

39. Javed F, Chotai M, Mehmood A, Almas K. Oral mucosal disorders associated with habitual gutka usage: a review. Oral Surg Oral Med Oral Pathol Oral Radiol. 2010;109(6):857-64. https:// doi.org/10.1016/j.tripleo.2009.12.038.

40. Kulkarni V, Uttamani JR, Bhatavadekar NB. Comparison of clinical periodontal status among habitual smokeless-tobacco users and cigarette smokers. Int Dent J. 2016;66(1):29-35. https://doi. org/10.1111/idj.12192.

41. Akram Z, Vohra F, Bukhari IA, Sheikh SA, Javed F. Clinical and radiographic peri-implant parameters and proinflammatory cytokine levels among cigarette smokers, smokeless tobacco users, and nontobacco users. Clin Implant Dent Relat Res. 2018;20(1): 76-81. https://doi.org/10.1111/cid.12575.

42. Ramoa CP, Eissenberg T, Sahingur SE. Increasing popularity of waterpipe tobacco smoking and electronic cigarette use: implications for oral healthcare. J Periodontal Res. 2017;52(5):813-23. https://doi.org/10.1111/jre.12458.

43. Sundar IK, Javed F, Romanos GE, Rahman I. E-cigarettes and flavorings induce inflammatory and pro-senescence responses in oral epithelial cells and periodontal fibroblasts. Oncotarget. 2016;7(47): 77196-204. https://doi.org/10.18632/oncotarget.12857.

44. Javed F, Abduljabbar T, Vohra F, Malmstrom H, Rahman I, Romanos GE. Comparison of periodontal parameters and selfperceived oral symptoms among cigarette smokers, individuals vaping electronic cigarettes, and never-smokers. J Periodontol. 2017;88(10):1059-65. https://doi.org/10.1902/jop.2017.170197.

45. Al-Aali KA, Alrabiah M, ArRejaie AS, Abduljabbar T, Vohra F, Akram Z. Peri-implant parameters, tumor necrosis factor-alpha, and interleukin-1 beta levels in vaping individuals. Clin Implant Dent Relat Res. 2018;20(3):410-5. https://doi.org/10.1111/cid. 12597.

46. Javed F, Kellesarian SV, Sundar IK, Romanos GE, Rahman I. Recent updates on electronic cigarette aerosol and inhaled nicotine effects on periodontal and pulmonary tissues. Oral Dis. 2017;23(8):1052-7. https://doi.org/10.1111/odi.12652.

47. Fergusson DM, Boden JM, Horwood LJ. Cannabis use and other illicit drug use: testing the cannabis gateway hypothesis. Addiction. 2006;101(4):556-69. https://doi.org/10.1111/j.13600443.2005.01322.x. 
48 Chisini LA, Cademartori MG, Francia A, Mederos M, Grazioli G, Conde MCM, et al. Is the use of Cannabis associated with periodontitis? A systematic review and meta-analysis. J Periodontal Res. 2019;54(4):311-7. https://doi.org/10.1111/jre.12639 Recent literature reviews detailing different peri-implantitis risk factors.

49. Hughes FJ, Bartold PM. Periodontal complications of prescription and recreational drugs. Periodontol. 2018;78(1):47-58. https://doi. org/10.1111/prd.12230.

50. Nogueira-Filho GR, Todescan S, Shah A, Rosa BT, Tunes Uda R, Cesar Neto JB. Impact of cannabis sativa (marijuana) smoke on alveolar bone loss: a histometric study in rats. J Periodontol. 2011;82(11):1602-7. https://doi.org/10.1902/jop.2011.100362.

51. Holde GE, Oscarson N, Trovik TA, Tillberg A, Jonsson B. Periodontitis prevalence and severity in adults: a cross-sectional study in Norwegian circumpolar communities. J Periodontol. 2017;88(10):1012-22. https://doi.org/10.1902/jop.2017.170164.

52. Slots J. Periodontitis: facts, fallacies and the future. Periodontol. 2017;75(1):7-23. https://doi.org/10.1111/prd.12221.

53. Do Y, McKallip RJ, Nagarkatti M, Nagarkatti PS. Activation through cannabinoid receptors 1 and 2 on dendritic cells triggers NF-kappaBdependent apoptosis: novel role for endogenous and exogenous cannabinoids in immunoregulation. J Immunol. 2004;173(4):2373-82. https://doi.org/10.4049/jimmunol.173.4.2373.

54. Guobis Z, Pacauskiene I, Astramskaite I. General diseases influence on peri-implantitis development: a systematic review. J Oral Maxillofac Res. 2016;7(3):e5. https://doi.org/10.5037/jomr.2016. 7305.

55. Turri A, Rossetti PH, Canullo L, Grusovin MG, Dahlin C. Prevalence of peri-implantitis in medically compromised patients and smokers: a systematic review. Int J Oral Maxillofac Implants. 2016;31(1):111-8. https://doi.org/10.11607/jomi.4149.

56. Monje A, Catena A, Borgnakke WS. Association between diabetes mellitus/hyperglycaemia and peri-implant diseases: systematic review and meta-analysis. J Clin Periodontol. 2017;44(6):636-48. https://doi.org/10.1111/jcpe.12724.

57. American DA. Diagnosis and classification of diabetes mellitus. Diabetes Care. 2010;33(Suppl 1):S62-9. https://doi.org/10.2337/ dc10-S062.

58. Lalla E, Papapanou PN. Diabetes mellitus and periodontitis: a tale of two common interrelated diseases. Nat Rev Endocrinol. 2011;7(12):738-48. https://doi.org/10.1038/nrendo.2011.106.

59. Knight ET, Liu J, Seymour GJ, Faggion CM Jr, Cullinan MP. Risk factors that may modify the innate and adaptive immune responses in periodontal diseases. Periodontol. 2016;71(1):2251. https://doi.org/10.1111/prd.12110.

60• Schwarz F, Derks J, Monje A, Wang HL. Peri-implantitis. J Periodontol. 2018;89(Suppl 1):S267-S90. https://doi.org/10. 1002/JPER.16-0350 The most recent systematic reviews with detailed overviews on their respective subjects.

61. Papi P, Letizia C, Pilloni A, Petramala L, Saracino V, Rosella D, et al. Peri-implant diseases and metabolic syndrome components: a systematic review. Eur Rev Med Pharmacol Sci. 2018;22(4): 866-75. https://doi.org/10.26355/eurrev_201802_14364.

62. Vohra F, Alkhudhairy F, Al-Kheraif AA, Akram Z, Javed F. Periimplant parameters and C-reactive protein levels among patients with different obesity levels. Clin Implant Dent Relat Res. 2018;20(2):130-6. https://doi.org/10.1111/cid.12556.

63. Obesity: preventing and managing the global epidemic. Report of a WHO consultation. World Health Organ Tech Rep Ser. 2000;894(i-xii):1-253.

64. Kopelman PG. Obesity as a medical problem. Nature. 2000;404(6778):635-43. https://doi.org/10.1038/35007508.
65. Akram Z, Abduljabbar T, Abu Hassan MI, Javed F, Vohra F. Cytokine profile in chronic periodontitis patients with and without obesity: a systematic review and meta-analysis. Dis Markers. 2016;2016:4801418-2. https://doi.org/10.1155/2016/4801418.

66. Abduljabbar T, Al-Sahaly F, Kellesarian SV, Kellesarian TV, AlAnazi M, Al-Khathami M, et al. Comparison of peri-implant clinical and radiographic inflammatory parameters and whole salivary destructive inflammatory cytokine profile among obese and nonobese men. Cytokine. 2016;88:51-6. https://doi.org/10.1016/j. cyto.2016.08.017.

67. Alkhudhairy F, Vohra F, Al-Kheraif AA, Akram Z. Comparison of clinical and radiographic peri-implant parameters among obese and non-obese patients: a 5-year study. Clin Implant Dent Relat Res. 2018;20(5):756-62. https://doi.org/10.1111/cid.12633.

68. Krennmair S, Weinlander M, Forstner T, Krennmair G, Stimmelmayr M. Factors affecting peri-implant bone resorption in four implant supported mandibular full-arch restorations: a 3year prospective study. J Clin Periodontol. 2016;43(1):92-101. https://doi.org/10.1111/jcpe.12469.

69. Ting M, Craig J, Balkin BE, Suzuki JB. Peri-implantitis: a comprehensive overview of systematic reviews. J Oral Implantol. 2018;44(3):225-47. https://doi.org/10.1563/aaid-joi-D-16-00122.

70. de Souza JG, Neto AR, Filho GS, Dalago HR, de Souza Junior JM, Bianchini MA. Impact of local and systemic factors on additional peri-implant bone loss. Quintessence Int. 2013;44(5):41524. https://doi.org/10.3290/j.qi.a29152.

71. Krennmair G, Seemann R, Piehslinger E. Dental implants in patients with rheumatoid arthritis: clinical outcome and peri-implant findings. J Clin Periodontol. 2010;37(10):928-36. https://doi.org/ 10.1111/j.1600-051X.2010.01606.x.

72. Korfage A, Raghoebar GM, Arends S, Meiners PM, Visser A, Kroese FG, et al. Dental implants in patients with Sjogren's syndrome. Clin Implant Dent Relat Res. 2016;18(5):937-45. https:// doi.org/10.1111/cid.12376.

73. Zahid TM, Wang BY, Cohen RE. Influence of bisphosphonates on alveolar bone loss around osseointegrated implants. J Oral Implantol. 2011;37(3):335-46. https://doi.org/10.1563/AAIDJOI-D-09-00114.

74.• Stavropoulos A, Bertl K, Pietschmann P, Pandis N, Schiodt M, Klinge B. The effect of antiresorptive drugs on implant therapy: systematic review and meta-analysis. Clin Oral Implants Res. 2018;29(Suppl 18):54-92. https://doi.org/10.1111/clr.13282 Recent literature reviews detailing different peri-implantitis risk factors.

75. Eguia Del Valle A, Lopez-Vicente J, Martinez-Conde R, AguirreZorzano LA. Current understanding of genetic polymorphisms as biomarkers for risk of biological complications in implantology. $\mathrm{J}$ Clin Exp Dent. 2018;10(10):e1029-e39. https://doi.org/10.4317/ jced.55141.

76. García-Delaney C, Sánchez-Garcés MÁ, Figueiredo R, SánchezTorres A, Gay-Escoda C. Clinical significance of interleukin-1 genotype in smoking patients as a predictor of peri-implantitis: a case-control study. Med Oral Patol Oral Cir Bucal. 2015;20(6): e737-e43. https://doi.org/10.4317/medoral.20655.

77. Dereka X, Mardas N, Chin S, Petrie A, Donos N. A systematic review on the association between genetic predisposition and dental implant biological complications. Clin Oral Implants Res. 2012;23(7):775-88. https://doi.org/10.1111/j.1600-0501.2011.02329.x.

78. Melo RF, Lopes BM, Shibli JA, Marcantonio E, Marcantonio RA, Galli GM. Interleukin- $1 \beta$ and interleukin- 6 expression and gene polymorphisms in subjects with peri-implant disease. Clin Implant Dent Relat Res. 2012;14(6):905-14. https://doi.org/10.1111/j. 1708-8208.2010.00325.x. 
79. He K, Jian F, He T, Tang H, Huang B, Wei N. Analysis of the association of TNF-alpha, IL-1A, and IL-1B polymorphisms with peri-implantitis in a Chinese non-smoking population. Clin Oral Investig. 2019;24:693-9. https://doi.org/10.1007/s00784-01902968-z.

80. Gruica B, Wang HY, Lang NP, Buser D. Impact of IL-1 genotype and smoking status on the prognosis of osseointegrated implants. Clin Oral Implants Res. 2004;15(4):393-400. https://doi.org/10. 1111/j.1600-0501.2004.01026.x.

81. Petkovic-Curcin A, Zeljic K, Cikota-Aleksic B, Dakovic D, Tatic $Z$, Magic Z. Association of cytokine gene polymorphism with peri-implantitis risk. Int J Oral Maxillofac Implants. 2017;32(5): e241-e8. https://doi.org/10.11607/jomi.5814.

82. Mo YY, Zeng XT, Weng H, Cen Y, Zhao Q, Wen X. Association between tumor necrosis factor-alpha G-308A polymorphism and dental peri-implant disease risk: a meta-analysis. Medicine (Baltimore). 2016;95(35):e4425. https://doi.org/10.1097/MD. 0000000000004425 .

83. Fu JH, Hsu YT, Wang HL. Identifying occlusal overload and how to deal with it to avoid marginal bone loss around implants. Eur J Oral Implantol. 2012;5(Suppl):S91-103.

84. Pellegrini G, Canullo L, Dellavia C. Histological features of periimplant bone subjected to overload. Ann Anat. 2016;206:57-63. https://doi.org/10.1016/j.aanat.2015.02.011.

85. Isidor F. Histological evaluation of peri-implant bone at implants subjected to occlusal overload or plaque accumulation. Clin Oral Implants Res. 1997;8(1):1-9.

86. Miyata T, Kobayashi Y, Araki H, Ohto T, Shin K. The influence of controlled occlusal overload on peri-implant tissue. Part 4: a histologic study in monkeys. Int J Oral Maxillofac Implants. 2002;17(3):384-90.

87. Gotfredsen K, Berglundh T, Lindhe J. Bone reactions at implants subjected to experimental peri-implantitis and static load. A study in the dog. J Clin Periodontol. 2002;29(2):144-51.

88. Miyata T, Kobayashi Y, Araki H, Motomura Y, Shin K. The influence of controlled occlusal overload on peri-implant tissue: a histologic study in monkeys. Int J Oral Maxillofac Implants. 1998;13(5):677-83.

89. Heitz-Mayfield LJ, Schmid B, Weigel C, Gerber S, Bosshardt DD, Jonsson J, et al. Does excessive occlusal load affect osseointegration? An experimental study in the dog. Clin Oral Implants Res. 2004;15(3):259-68. https://doi.org/10.1111/j. 1600-0501.2004.01019.x.

90. Dalago HR, Schuldt Filho G, Rodrigues MA, Renvert S, Bianchini MA. Risk indicators for peri-implantitis. A crosssectional study with 916 implants. Clin Oral Implants Res. 2017;28(2):144-50. https://doi.org/10.1111/clr.12772.

91. Merin RL. Repair of peri-implant bone loss after occlusal adjustment: a case report. J Am Dent Assoc. 2014;145(10):1058-62. https://doi.org/10.14219/jada.2014.65.

92. Passanezi E, Sant'Ana AC, Damante CA. Occlusal trauma and mucositis or peri-implantitis? J Am Dent Assoc. 2017;148(2): 106-12. https://doi.org/10.1016/j.adaj.2016.09.009.

93. De Bruyn H, Christiaens V, Doornewaard R, Jacobsson M, Cosyn $\mathrm{J}$, Jacquet $\mathrm{W}$, et al. Implant surface roughness and patient factors on long-term peri-implant bone loss. Periodontol. 2017;73(1): 218-27. https://doi.org/10.1111/prd.12177.

94. Dank A, Aartman IHA, Wismeijer D, Tahmaseb A. Effect of dental implant surface roughness in patients with a history of periodontal disease: a systematic review and meta-analysis. Int $\mathbf{J}$ Implant Dent. 2019;5(1):12. https://doi.org/10.1186/s40729-0190156-8.
95. Rasperini G, Maglione M, Cocconcelli P, Simion M. In vivo early plaque formation on pure titanium and ceramic abutments: a comparative microbiological and SEM analysis. Clin Oral Implants Res. 1998;9(6):357-64.

96. Albouy JP, Abrahamsson I, Persson LG, Berglundh T. Implant surface characteristics influence the outcome of treatment of periimplantitis: an experimental study in dogs. J Clin Periodontol. 2011;38(1):58-64. https://doi.org/10.1111/j.1600-051X.2010. 01631.x.

97. Marrone A, Lasserre J, Bercy P, Brecx MC. Prevalence and risk factors for peri-implant disease in Belgian adults. Clin Oral Implants Res. 2013;24(8):934-40. https://doi.org/10.1111/j. 1600-0501.2012.02476.x.

98. Dvorak G, Arnhart C, Heuberer S, Huber CD, Watzek G, Gruber R. Peri-implantitis and late implant failures in postmenopausal women: a cross-sectional study. J Clin Periodontol. 2011;38(10): 950-5. https://doi.org/10.1111/j.1600-051X.2011.01772.x.

99.• Doornewaard R, Jacquet W, Cosyn J, De Bruyn H. How do periimplant biologic parameters correspond with implant survival and peri-implantitis? A critical review. Clin Oral Implants Res. 2018;29(Suppl 18):100-23. https://doi.org/10.1111/clr.13264 Recent literature reviews detailing different peri-implantitis risk factors.

100. Hashim D, Cionca N, Courvoisier DS, Mombelli A. A systematic review of the clinical survival of zirconia implants. Clin Oral Investig. 2016;20(7):1403-17. https://doi.org/10.1007/s00784016-1853-9.

101. Linares A, Grize L, Munoz F, Pippenger BE, Dard M, Domken O, et al. Histological assessment of hard and soft tissues surrounding a novel ceramic implant: a pilot study in the minipig. J Clin Periodontol. 2016;43(6):538-46. https://doi.org/10.1111/jcpe.12543.

102•• Cionca N, Hashim D, Mombelli A. Zirconia dental implants: where are we now, and where are we heading? Periodontol. 2017;73(1):241-58. https://doi.org/10.1111/prd.12180. The most recent systematic reviews with detailed overviews on their respective subjects.

103. Roehling S, Astasov-Frauenhoffer M, Hauser-Gerspach I, Braissant $\mathrm{O}$, Woelfler $\mathrm{H}$, Waltimo $\mathrm{T}$, et al. In vitro biofilm formation on titanium and zirconia implant surfaces. J Periodontol. 2017;88(3):298-307. https://doi.org/10.1902/jop.2016.160245.

104. Degidi M, Artese L, Scarano A, Perrotti V, Gehrke P, Piattelli A. Inflammatory infiltrate, microvessel density, nitric oxide synthase expression, vascular endothelial growth factor expression, and proliferative activity in peri-implant soft tissues around titanium and zirconium oxide healing caps. J Periodontol. 2006;77(1):7380. https://doi.org/10.1902/jop.2006.77.1.73.

105. Cionca N, Hashim D, Cancela J, Giannopoulou C, Mombelli A. Pro-inflammatory cytokines at zirconia implants and teeth. A cross-sectional assessment. Clin Oral Investig. 2016;20(8):228591. https://doi.org/10.1007/s00784-016-1729-z.

106• Roehling S, Gahlert M, Janner S, Meng B, Woelfler H, Cochran DL. Ligature-induced peri-implant bone loss around loaded zirconia and titanium implants. Int J Oral Maxillofac Implants. 2019;34(2):35765. https://doi.org/10.11607/jomi.7015 Represent most recent clinical studies highlighting emerging concepts.

107. Pieralli S, Kohal RJ, Jung RE, Vach K, Spies BC. Clinical outcomes of zirconia dental implants. J Dent Res. 2017;96(1):38-46. https://doi.org/10.1177/0022034516664043.

108. Ferreira SD, Silva GL, Cortelli JR, Costa JE, Costa FO. Prevalence and risk variables for peri-implant disease in Brazilian subjects. J Clin Periodontol. 2006;33(12):929-35. https://doi.org/10.1111/j.1600-051X.2006.01001.x. 
109. Katafuchi M, Weinstein BF, Leroux BG, Chen YW, Daubert DM. Restoration contour is a risk indicator for peri-implantitis: a crosssectional radiographic analysis. J Clin Periodontol. 2018;45(2): 225-32. https://doi.org/10.1111/jcpe.12829.

110. Quaranta A, Lim ZW, Tang J, Perrotti V, Leichter J. The impact of residual subgingival cement on biological complications around dental implants: a systematic review. Implant Dent. 2017;26(3): 465-74. https://doi.org/10.1097/ID.0000000000000593.

111. Staubli N, Walter C, Schmidt JC, Weiger R, Zitzmann NU. Excess cement and the risk of peri-implant disease-a systematic review. Clin Oral Implants Res. 2017;28(10):1278-90. https://doi.org/10. 1111/clr.12954.

112. Hsu YT, Lin GH, Wang HL. Effects of platform-switching on peri-implant soft and hard tissue outcomes: a systematic review and meta-analysis. Int J Oral Maxillofac Implants. 2017;32(1):e9e24. https://doi.org/10.11607/jomi.5140.

113. Monje A, Pommer B. The concept of platform switching to preserve peri-implant bone level: assessment of methodologic quality of systematic reviews. Int J Oral Maxillofac Implants. 2015;30(5): 1084-92. https://doi.org/10.11607/jomi.4103.

114 Sasada Y, Cochran DL. Implant-abutment connections: a review of biologic consequences and peri-implantitis implications. Int $\mathrm{J}$ Oral Maxillofac Implants. 2017;32(6):1296-307. https://doi.org/ 10.11607/jomi.5732 Recent literature reviews detailing different peri-implantitis risk factors.

115. Pimentel SP, Shiota R, Cirano FR, Casarin RCV, Pecorari VGA, Casati MZ, et al. Occurrence of peri-implant diseases and risk indicators at the patient and implant levels: a multilevel crosssectional study. J Periodontol. 2018;89(9):1091-100. https://doi. org/10.1002/JPER.17-0599.

116 Alrabeah GO, Knowles JC, Petridis H. Reduction of tribocorrosion products when using the platform-switching concept. J Dent Res. 2018;97(9):995-1002. https://doi.org/10.1177/ 0022034518765751 Represent most recent clinical studies highlighting emerging concepts.

117•• Mombelli A, Hashim D, Cionca N. What is the impact of titanium particles and biocorrosion on implant survival and complications? A critical review. Clin Oral Implants Res. 2018;29(Suppl 18):37-53. https://doi.org/10.1111/clr.13305 The most recent systematic reviews with detailed overviews on their respective subjects.

118. Giovannoli JL, Roccuzzo M, Albouy JP, Duffau F, Lin GH, Serino G. Local risk indicators-consensus report of working group 2. Int Dent J. 2019;69(Suppl 2):7-11. https://doi.org/10.1111/idj.12511.

119. Isler SC, Uraz A, Kaymaz O, Cetiner D. An evaluation of the relationship between peri-implant soft tissue biotype and the severity of peri-implantitis: a cross-sectional study. Int J Oral Maxillofac Implants. 2019;34(1):187-96. https://doi.org/10. 11607/jomi.6958.

120. Fiorellini JP, Luan KW, Chang YC, Kim DM, Sarmiento HL. Peri-implant mucosal tissues and inflammation: clinical implications. Int J Oral Maxillofac Implants. 2019;34:s25-33. https://doi. org/10.11607/jomi.19suppl.g2.

121. Ladwein C, Schmelzeisen R, Nelson K, Fluegge TV, Fretwurst T. Is the presence of keratinized mucosa associated with periimplant tissue health? A clinical cross-sectional analysis. Int J Implant Dent. 2015;1(1):11. https://doi.org/10.1186/s40729-015-0009-z.

122. Roccuzzo M, Grasso G, Dalmasso P. Keratinized mucosa around implants in partially edentulous posterior mandible: 10-year results of a prospective comparative study. Clin Oral Implants Res. 2016;27(4):491-6. https://doi.org/10.1111/clr.12563.

123. Perussolo J, Souza AB, Matarazzo F, Oliveira RP, Araujo MG. Influence of the keratinized mucosa on the stability of peri-implant tissues and brushing discomfort: a 4-year follow-up study. Clin
Oral Implants Res. 2018;29(12):1177-85. https://doi.org/10.1111/ clr.13381.

124. Wada M, Mameno T, Onodera Y, Matsuda H, Daimon K, Ikebe $\mathrm{K}$. Prevalence of peri-implant disease and risk indicators in a Japanese population with at least 3 years in function-a multicentre retrospective study. Clin Oral Implants Res. 2019;30(2):111-20. https://doi.org/10.1111/clr.13397.

125. Monje A, Blasi G. Significance of keratinized mucosa/gingiva on peri-implant and adjacent periodontal conditions in erratic maintenance compliers. J Periodontol. 2019;90(5):445-53. https://doi. org/10.1002/JPER.18-0471.

126. Frisch E, Ziebolz D, Vach K, Ratka-Kruger P. The effect of keratinized mucosa width on peri-implant outcome under supportive postimplant therapy. Clin Implant Dent Relat Res. 2015;17(Suppl 1):e236-44. https://doi.org/10.1111/cid.12187.

127. Passoni BB, Dalago HR, Schuldt Filho G, Oliveira de Souza JG, Benfatti CA, Magini RES, et al. Does the number of implants have any relation with peri-implant disease? J Appl Oral Sci : revista FOB. 2014;22(5):403-8.

128. Canullo L, Tallarico M, Radovanovic S, Delibasic B, Covani U, Rakic M. Distinguishing predictive profiles for patient-based risk assessment and diagnostics of plaque induced, surgically and prosthetically triggered peri-implantitis. Clin Oral Implants Res. 2016;27(10):1243-50. https://doi.org/10.1111/clr.12738.

129. Lindhe J, Lang NP, Berglundh T, Giannobile WV, Sanz M. Clinical periodontology and implant dentistry. Sixth edition. ed. Chichester: West Sussex, John Wiley and Sons, Inc.; 2015.

130. Salvi GE, Monje A, Tomasi C. Long-term biological complications of dental implants placed either in pristine or in augmented sites: a systematic review and meta-analysis. Clin Oral Implants Res. 2018;29(Suppl 16):294-310. https://doi.org/10.1111/clr.13123.

131. Noronha Oliveira M, Schunemann WVH, Mathew MT, Henriques B, Magini RS, Teughels W, et al. Can degradation products released from dental implants affect peri-implant tissues? J Periodontal Res. 2018;53(1):1-11. https://doi.org/10. 1111/jre.12479.

132. Delgado-Ruiz R, Romanos G. Potential causes of titanium particle and ion release in implant dentistry: a systematic review. Int J Mol Sci. 2018;19(11):3585. https://doi.org/10.3390/ijms19113585.

133. Souza J, Barbosa S, Ariza E, Celis J-P, Rocha L. Simultaneous degradation by corrosion and wear of titanium in artificial saliva containing fluorides. Wear. 2012;292:82-8.

134. Urban RM, Jacobs JJ, Tomlinson MJ, Gavrilovic J, Black J, Peoc'h M. Dissemination of wear particles to the liver, spleen, and abdominal lymph nodes of patients with hip or knee replacement. J Bone Joint Surg. 2000;82(4):457-76. https://doi.org/10. 2106/00004623-200004000-00002.

135. Wachi T, Shuto T, Shinohara Y, Matono Y, Makihira S. Release of titanium ions from an implant surface and their effect on cytokine production related to alveolar bone resorption. Toxicology. 2015;327:1-9. https://doi.org/10.1016/j.tox.2014.10.016.

136. Pettersson M, Kelk P, Belibasakis GN, Bylund D, Molin Thoren $\mathrm{M}$, Johansson A. Titanium ions form particles that activate and execute interleukin-1beta release from lipopolysaccharide-primed macrophages. J Periodontal Res. 2017;52(1):21-32. https://doi. org/10.1111/jre.12364.

137. Fretwurst T, Nelson K, Tarnow DP, Wang HL, Giannobile WV. Is metal particle release associated with peri-implant bone destruction? An emerging concept. J Dent Res. 2018;97(3):259-65. https://doi.org/10.1177/0022034517740560.

138. Faverani LP, Barao VA, Pires MF, Yuan JC, Sukotjo C, Mathew MT, et al. Corrosion kinetics and topography analysis of Ti-6Al$4 \mathrm{~V}$ alloy subjected to different mouthwash solutions. Mater Sci 
Eng C Mater Biol Appl. 2014;43:1-10. https://doi.org/10.1016/j. msec.2014.06.033.

139. Harrel SK, Wilson TG Jr, Pandya M, Diekwisch TGH. Titanium particles generated during ultrasonic scaling of implants. J Periodontol. 2019;90(3):241-6. https://doi.org/10.1002/JPER.180230.

140•• Heitz-Mayfield LJA, Salvi GE. Peri-implant mucositis. J Periodontol. 2018;89(Suppl 1):S257-S66. https://doi.org/10. 1002/JPER.16-0488 The most recent systematic reviews with detailed overviews on their respective subjects.

141. Meyer S, Giannopoulou C, Courvoisier D, Schimmel M, Muller F, Mombelli A. Experimental mucositis and experimen gingivitis in persons aged 70 or over. Clinical and biological responses. Clin
Oral Implants Res. 2017;28(8):1005-12. https://doi.org/10.1111/clr. 12912.

142. Gualini F, Berglundh T. Immunohistochemical characteristics of inflammatory lesions at implants. J Clin Periodontol. 2003;30(1): 14-8. https://doi.org/10.1034/j.1600-051x.2003.300103.x.

143. Costa FO, Takenaka-Martinez S, Cota LOM, Ferreira SD, Silva GLM, Costa JE. Peri-implant disease in subjects with and without preventive maintenance: a 5-year follow-up. J Clin Periodontol. 2012;39(2):173-81. https://doi.org/10.1111/j.1600-051X.2011. 01819.x.

Publisher's Note Springer Nature remains neutral with regard to jurisdictional claims in published maps and institutional affiliations. 